\title{
PENGARUH MODEL PEMBELAJARAN DISCOVERY LEARNING TERHADAP HASIL BELAJAR SISWA PADA MATERI POKOK LISTRIK DINAMIS DI SMA NEGERI 11 MEDAN
}

\author{
Rika Sari Indah Harahap dan Eidi Sihombing \\ Jurusan Fisika FMIPA Universitas Negeri Medan \\ rikaharahap@gmail.com
}

\begin{abstract}
ABSTRAK
Tujuan penelitian ini untuk mengetahui pengaruh model pembelajaran discovery learning terhadap hasil belajar fisika mengenai listrik dinamis di SMA Negeri 11 Medan. Penelitian quasi eksperimen ini mempunyai populasi seluruh siswa kelas X SMA Negeri 11 Medan sebanyak delapan kelas dengan mengambil sampel dua kelas dengan cara cluster random sampling. Instrumen yang digunakan untuk mengetahui hasil belajar siswa adalah tes hasil belajar dalam bentuk essay tes dengan jumlah delapan soal. Hasil kemampuan siswa untuk kedua kelas sebelum perlakuan diberikan menunjukkan kemampuan yang relatif sama. Hasil kemampuan setelah perlakuan menunjukkan bahwa kemampuan kelas eksperimen yang menggunakan pembelajaran discovery learning lebih tinggi dibanding siswa yang berada di kelas kontrol dengan pembelajaran konvensional.
\end{abstract}

Kata Kunci: model pembelajaran discovery learning, pembelajaran konvensional

\begin{abstract}
This study aims to determine the effect of discovery learning model on learning outcomes matter physics class $X$ second semester in the subject matter of the Dynamic electricity in SMA Negeri 11 Medan T.A. 2014/2015. This research is a quasi experiment. The population in this study were all students of class $X$ second semester SMA Negeri 11 Medan consist of eight classes. The study sample was taken from two classes, namely class $X_{2}$ (as a control class) and class $X_{1}$ (as a experiment class), each numbered 37 people were determined by means of cluster random sampling. Instrument used to determine student learning outcomes is the achievement test in the form of essay test which amounts 8 matter. Results of this study to obtain pre-test average value was 21.94 in the experiment class and control class is 22.47. After learning is completed given postes obtained with the average in the experiment class is 70.01 and the control class is 65.79. The test results by $t$ test at significance level $(\alpha)=0,05$ obtained tarithmetic $=1.68$ and $t_{\text {table }}=$ 1.66 , so tarithmetic $>$ table $(1.68>1.66)$ then $H_{a}$ accepted. So obtained that there is influence discovery learning model to student learning outcomes in the subject matter in class X Dynamic Electricity the second semester in SMA Negeri 11 Medan T.A. 2014/2015.
\end{abstract}

Keywords: discovery learning model, conventional learning.

\section{PENDAHULUAN}

Standar Nasional Pendidikan adalah kriteria minimal tentang sistem pendidikan di seluruh wilayah hukum Negara Kesatuan Republik Indonesia. Standar Nasional Pendidikan terdiri dari: 1) Standar Kompetensi Lulusan; 2) Standar Isi; 3) Standar Proses; 4) Standar Pendidikan dan Tenaga
Kependidikan; 5) Standar Sarana dan Prasarana; 6) Standar Pengelolaan; 7) Standar Pembiayaan Pendidikan; 8) Standar Penilaian Pendidikan. Fungsi dan Tujuan Standar: 1) Standar Nasional Pendidikan berfungsi sebagai dasar dalam perencanaan, pelaksanaan, dan pengawasan pendidikan dalam rangka mewujudkan 
pendidikan nasional yang bermutu; 2) Standar Nasional Pendidikan bertujuan menjamin mutu pendidikan nasional dalam rangka mencerdaskan kehidupan bangsa dan membentuk watak serta peradaban bangsa yang bermartabat; 3) Standar Nasional Pendidikan disempurnakan secara terencana, terarah, dan berkelanjutan sesuai dengan tuntutan perubahan kehidupan lokal, nasional, dan global. ( BNSP (2008), http://bsnpindonesia.org/id/?page id=61, (diakses 17 Januari 2015).

Fisika merupakan bagian dari Ilmu Pengetahuan Alam (IPA) yang mencakup produk, proses dan sikap ilmiah. Produk IPA antara lain konsep, hukum, dan teori-teori. Fisika merupakan suatu teori yang mempelajari gejala-gejala alam, yang hasilnya dirumuskan dalam bentuk definisi ilmiah dan persamaan matematika berdasarkan hasil pengamatan dan penyelidikan. Fisika juga dikatakan bahwa suatu ilmu pengetahuan yang menguraikan dan menganalisa struktur dan peristiwa alam kemudian menjelaskan dengan cara yang

sederhana, sehingga menghasilkan aturan-aturan atau hukum. Mata pelajaran fisika adalah salah satu mata pelajaran dalam rumpun sains. Fisika merupakan bagian dari sains yang memungkinkan manusia memperoleh kebenaran ilmiah dari fenomenafenomena alam sehingga memudahkan menggambarkan dan mengatur alam, selain itu, mata pelajaran fisika merupakan mata pelajaran yang berfungsi mengembangkan semua aspek belajar yang dimiliki peserta didik (afektif, kognitif, dan psikomotor) sehingga mempunyai sikap percaya diri untuk bekal hidup di masyarakat.

Hasil observasi awal di sekolah SMA Negeri 11 Medan memberikan kesimpulan bahwa kegiatan pembelajaran yang diterapkan dikelas masih cenderung menggunakan metode ceramah yaitu berpusat pada guru (Teacher-centered), mencatat dan mengerjakan soal sehingga siswa menjadi tidak aktif, pasif dan belum dapat menciptakan pembelajaran yang berpusat kepada siswa (StudentCentered) yang mana guru hanya berperan sebagai fasilitator. Permasalahan tersebut menyebabkan hasil belajar siswa kelas sepuluh masih tergolong rendah yang dinyatakan dari nilai ujian tengah semester.

Berdasarkan dari uraian tersebut, masalah yang terjadi saat ini adalah bagaimana cara untuk mengatasi permasalahan di atas yakni dengan mengembangkan model pembelajaran yang efektif, yang dapat menumbuhkan rasa ingin tahu siswa, menumbuhkan kemampuan berfikir kritis siswa, menarik perhatian siswa, membangkitkan motivasi siswa, melibatkan siswa secara aktif dan memperhatikan kemampuan siswa. Salah satu alternative yang dapat digunakan untuk mengatasi kesulitan tersebut adalah dengan mencipatakan susasana pembelajaran yang langsung berhunbungan dengan kehidupan sehari-hari.

Model pembelajaran melalui penemuan adalah salah satu upaya solusinya, penemuan (discovery) merupakan suatu model pembelajaran yang dikembangkan berdasarkan pandangan konstruktivisme. Model ini menekankan pentingnya pemahaman struktur atau ide-ide penting terhadap suatu disiplin ilmu, melalui keterlibatan siswa secara aktif dalam proses pembelajaran. Model pembelajaran discovery merupakan suatu cara untuk mengembangkan belajar siswa aktif dengan menemukan sendiri, menyelidiki sendiri, maka hasil yang akan diperoleh akan tahan lama dalam ingatan (Hosnan, 2014:281; Kusuma, at all., 2015; Goldberg, at all., 2012 ).

Pada abad ke-21, penciptaan adalah salah satu faktor penting dari proses belajar mengajar. Dalam rangka 
menciptakan dalam proses belajar mengajar, guru biasanya menggunakan metode akrab menjadi pembelajaran penemuan. Metode ini membuktikan aktivitas siswa. Saat ini, dengan bantuan teknologi, metode belajar mengajar berubah. Dengan bantuan teknologi, siswa memiliki metode miring lebih baik dan efektif daripada yang tradisional (Tran, at all, 2014).

Belajar dengan penemuan adalah teknik untuk membantu peserta didik membuat dan mengatur pengetahuan. Melibatkan partisipasi sadar dan penyelidikan aktif, biasanya berlangsung selama situasi pemecahan masalah. Pelajar mengacu pada pengetahuan dan pengalaman masa lalu untuk menyimpulkan strategi yang mendasari dan memperoleh pemahaman tentang konsep-konsep. Teori tradisional pembelajaran menunjukkan bahwa penemuan memainkan peran penting dalam mempelajari konsep-konsep abstrak dan dalam meningkatkan ketekunan dan kreativitas siswa. Teori yang lebih baru juga telah menekankan pandangan anak sebagai peserta aktif, sebagai lawan dari penerima pasif, dalam proses pembelajaran, misalnya, teori berpendapat bahwa anak-anak belajar dalam proses mirip dengan metode ilmiah: memeriksa pengalaman saat dalam menghadapi keyakinan sebelumnya atau teori. Anak-anak mencari mendasari penyebab fenomena dan dapat menjadi penasaran dalam menghadapi data membingungkan atau anomali perspektif yang dihasilkan adalah seorang anak yang bisa mendapatkan keuntungan dan belajar melalui penemuan (Honomichl, at all., 2012).

Pemaparan tentang penelitian sebelumnya yang berkaitan dengan pembelajaran discovery learning diantaranya: hasil penelitian Kusuma(2015) bahwa discovery learning disertai teknik probingprompting berpengaruh signifikan terhadap hasil belajar fisika siswa.
Putrayasa, at all.,(2014) mengatakan penerapan model pembelajaran discoverylearning terutama mata pelajaran IPA menjadi sangat tepat dikarenakan model ini memiliki beberapa kelebihan, yaitu : 1) menambah pengalaman siswa dalam belajar, 2) memberikan kesempatan kepada siswa untuk lebih dekat lagi dengan sumber pengetahuan selain buku, 3) menggali kreatifitas siswa, 4) mampu meningkatkan rasa percaya diri pada siswa, dan 5) meningkatkan kerja sama antar siswa. Widiadnyana, at all., (2014) mengatakan bahwa terdapat perbedaan sikap ilmiah secara siginifikan antara siswa yang belajar menggunakan model discovery learning dengan siswa yang belajar menggunakan model pengajaran langsung. Syafi'I, at all., (2014) mengatakan bahwa penerapan question based discovery learning pada kegiatan laboratorium fisika dapat meingkatkan keterampilan proses sains siswa. Uside, at all., (2013) mengatakan model pembelajaran discovery learning memiliki pengaruh yang signifikan terhadap pencapaian siswa dengan meningkatkan retensi pengetahuan dan menanamkan kepercayaan diri. Kamel, at all., (2014) mengatakan bahwa dari pembelajaran penemuan terdapat pengembangan keterampilan dari metakognisi.

Hasil penelitian di atas menunjukkan ada pengaruh yang signifikan antara model pembelajaran discovery learning terhadap hasil belajar siswa. Model tersebut siswa dituntut untuk menemukan sendiridan mentransformasikan informasi kompleks .

Kegiatan pembelajaran yang di tawarkan adalah: a) memberikan masalah-masalah yang bersifat nyata kepada siswa, b) memakai pendekatan saintifik 5M (mengamati, menanya, menalar, mencoba, membentuk jaringan) dalam pembalajaran, c) membagi siswa dalam kelompok yang terdiri dari 5 siswa, d) mengarahkan 
siswa membuat hipotesis, e) Melakukan tanya jawab kepada siswa, f) membimbing siswa untuk membuktikan hipotesis siswa melalui percobaan dengan memberikan LKS, g) membimbing siswa membuat kesimpulan dari hasil percobaan, h) memberikan contoh soal dan latihan.

Tujuan penelitian ini untuk mengetahui hasil belajar siswa dengan model pembelajaran discovery learning dan model pembelajaran konvensional, mengetahui aktivitas proses pembelajaran dengan menggunakan model pembelajaran discovery learning dan pembelajaran konvensional, mengetahui pengaruh model pembelajaran discovery learning terhadap hasil belajar siswa.

Tabel 1. Sintaks Model Discovery Learning

\begin{tabular}{|c|c|}
\hline Indikator & $\begin{array}{l}\text { Aktifitas / Kegiatan } \\
\text { Guru }\end{array}$ \\
\hline Stimulation & $\begin{array}{l}\text { Guru menjelaskan } \\
\text { tujuan } \\
\text { pembelajaran dan } \\
\text { memulai kegiatan } \\
\text { PBM dengan } \\
\text { mengajukan } \\
\text { pertanyaan, } \\
\text { anjuran membaca } \\
\text { buku, dan aktivitas } \\
\text { belajar lainnya yang } \\
\text { mengarah pada } \\
\text { persiapan } \\
\text { pemecahan } \\
\text { masalah. }\end{array}$ \\
\hline $\begin{array}{l}\text { Problem } \\
\text { statement }\end{array}$ & $\begin{array}{l}\text { Guru memberi } \\
\text { kesempatan kepada } \\
\text { siswa untuk } \\
\text { mengidentifikasi } \\
\text { sebanyak mungkin } \\
\text { agenda-agenda } \\
\text { masalah yang } \\
\text { relevan dengan } \\
\text { bahan pelajaran, } \\
\text { kemudian salah } \\
\text { satunya dipilih dan } \\
\text { dirumuskan dalam } \\
\text { bentuk hipotesis } \\
\text { (jawaban sementara } \\
\text { atas pertanyaan } \\
\text { masalah). }\end{array}$ \\
\hline
\end{tabular}

\begin{tabular}{ll}
\hline & Ketika eksplorasi \\
& berlangsung guru \\
& juga memberi \\
& kesempatan kepada \\
para siswa untuk & mengumpulkan \\
Data collection & informasi sebanyak- \\
& banyaknya yang \\
& relevan untuk \\
& membuktikan benar \\
& atau tidaknya \\
& hipotesis. \\
& Guru mengolah \\
data dan informasi \\
yang telah diperoleh \\
para siswa baik \\
melalui wawancara, \\
observasi, dan \\
sebagainya, lalu \\
ditafsirkan. \\
\hline Guru memberikan \\
kesempatan kepada \\
siswa untuk \\
menemukan suatu \\
konsep, teori, \\
aturan atau \\
pemahaman melalui \\
contoh-contoh yang \\
ia jumpai dalam \\
kehidupannya. \\
Guru membimbing \\
siswa menarik \\
kesimpulan yang \\
dapat dijadikan \\
prinsip umum dan \\
berlaku untuk \\
semua kejadian \\
atau masalah yang \\
sama, dengan \\
memperhatikan \\
hasil verifikasi.
\end{tabular}

\section{METODE PENELITIAN}

Penelitian ini adalah kuasi eksperimen dengan populasi seluruh siswa kelas X SMA Negeri 11 Medan dan sampel ditentukan dengan cara teknik kelas acak (cluster random sampling) sebanyak 2 kelas, yaitu: satu kelas dijadikan kelas eksperimen dengan menggunakan model pembelajaran discovery learning dan kelas lainya dijadikan kelas kontrol dengan menggunakan model pembelajaan konvensional. Desain 
penelitian ini dapat dilihat pada tabel berikut ini:

Tabel 2. Two Group Pretest-Posttest Design

\begin{tabular}{cccc}
\hline Kelas & Pretest & Perlakuan & Postest \\
\hline $\begin{array}{c}\text { Eksperime } \\
\mathrm{n}\end{array}$ & $\mathrm{T}_{1}$ & $\mathrm{X}_{1}$ & $\mathrm{~T}_{2}$ \\
\hline Kontrol & $\mathrm{T}_{1}$ & $\mathrm{X}_{2}$ & $\mathrm{~T}_{2}$ \\
\hline
\end{tabular}

Keterangan :

$\mathrm{X}_{1}$ : pembelajaran menggunakan model pembelajaran discovery learning.

$\mathrm{X}_{2}$ : pembelajaran menggunakan model pembelajaran konvensional

$\mathrm{T}_{1}$ : Pretest diberikan kepada kelas eksperimen dan kelas kontrol sebelum perlakuan.

$\mathrm{T}_{2}$ : Postest diberikan setelah perlakuan pada kelas eksperimen dan kelas kontrol.

Data-data yang diperoleh terlebih dahulu dianalisis dengan uji hipotesis, setelah terlebih dahulu diuji normalitas dan uji homogenitas data.

Uji normalitas diadakan untuk mengetahui normal tidaknya data penelitian tiap variabel penelitian, uji yang dipakai adalah uji Lilliefors, kemudian uji homogenitas untuk mengetahui kedua sampel berasal dari populasi yang homogen, dengan menggunakan persamaan:

$$
F_{\text {hitung }}=\frac{\text { varians terbesar }}{\text { varians terkecil }}=\frac{s_{1}^{2}}{s_{2}^{2}}
$$

dengan kriteria pengujian, yaitu:

Jika $\mathrm{F}_{\text {hit }}<\mathrm{F}_{\text {tab1/2a(v1,v2), }} H_{o}$ diterima

Jika $\quad \mathrm{F}_{\text {hit }}>\mathrm{F}_{\text {tab1/2a(v1,v2, }} H_{\text {oditolak }}$ dengan taraf nyata $\alpha=0,10$. Jika pengolahan data menunjukkan bahwa $\mathrm{F}_{\text {hitung }}<\mathrm{F}_{\text {tabel }}$ maka $\mathrm{H}_{0}$ diterima, dapat diambil kesimpulan bahwa kedua sampel mempunyai varians yang homogen. Jika pengolahan data menunjukkan bahwa $\mathrm{F}_{\text {hitung }}>\mathrm{F}_{\text {tabel }}$ maka $\mathrm{H}_{0}$ ditolak dan terima $\mathrm{H}_{\mathrm{a}}$, dapat diambil kesimpulan bahwa kedua sampel tidak mempunyai varians yang homogen.

Pengujian hipotesis dilakukan dengan uji t dua pihak uji kesamaan rata-rata pretest dan uji $t$ satu pihak (uji kesamaan rata-rata postes). Uji t dua pihak digunakan untuk mengetahui kesamaan kemampuan awal siswa pada kedua kelompok sampel. Hipotesis yang diuji berbentuk :

$\mathrm{H}_{0}: \mu_{1}=\mu_{2}$ kelas eksperimen dan kelas kontrol mempunyai kemampuan awal sama.

$\mathrm{H}_{\mathrm{a}}: \mu_{1} \neq \mu_{2}$ kelas eksperimen dan kelas kontrol mempunyai kemempuan awal berbeda.

Data penelitian yang telah berdistribusi normal dan homogen akan diuji hipotesis menggunakan uji- $t$.

Kriteria pengujian adalah : terima Ho jika $\quad-t_{1-1 / 2} \alpha<t<t_{1-1 / 2} \alpha$ dimana $t_{1-1 / 2} \alpha$ didapat dari daftar distribusi $\mathrm{t}$ dengan $\mathrm{dk}=\left(\mathrm{n}_{1}+\mathrm{n}_{2}-2\right)$ dan $\alpha=0,05$. Untuk harga t lainnya Ho ditolak.

Uji t satu pihak digunakan untuk mengetahui pengaruh dari suatu perlakuan yaitu model pembelajaran discovery learning terhadap hasil belajar siswa. Hipotesis yang diuji berbentuk:

$$
\begin{aligned}
& \mathrm{H}_{0}: \mu_{1} \leq \mu_{2} \\
& \mathrm{H}_{\mathrm{a}}: \mu_{1}>\mu_{2}
\end{aligned}
$$

keterangan :

$\mu_{1} \leq \mu_{2}$ : Hasil belajar siswa pada kelas eksperimen lebih kecil atau sama dengan kelas kontrol, berarti tidak ada pengaruh model pembelajaran discovery learning terhadap hasil belajar siswa.

\section{HASIL DAN PEMBAHASAN}

Hasil penelitian, sebelum diberikan pembelajaran kepada kedua kelompok sampel diperoleh rata-rata pretes siswa kelas eksperimen sebesar 21,94 dan kelas kontrol sebesar 22,47. Pembelajaran pada kelas eksperimen dan kelas kontrol diberikan dengan dua perlakuan yang berbeda, pada kelas eksperimen diberi pembelajaran dengan model pembelajaran discovery learning dan kelas kontrol dengan model pembelajaran konvensional maka diperoleh rata-rata postes untuk kelas 
eksperimen sebesar 70,01 dan kelas kontrol 65,79.

Kelas eksperimen dengan menggunakan model pembelajaran discovery learning dan kelas kontrol menggunakan model pembelajaran konvensional, diperoleh perhitungan uji hipotesis sebagai berikut : $t_{\text {hitung }}>t_{\text {tabel }}=$ $1,68>1,66$, maka $\mathrm{Ho}$ ditolak dan $\mathrm{H}_{\mathrm{a}}$ diterima atau dengan kata lain ada pengaruh model pembelajaran discovery learning dalam meningkatkan hasil belajar siswa.

Peningkatan hasil belajar menggunakan model pembelajaran discovery learning lebih baik dikarenakan model pembelajaran ini memiliki beberapa kelebihan yaitu : 1) siswa belajar untuk memperoleh pengetahuan dan melatih kemampuan intelektual siswa, 2) merangsang keingintahuan dan memotivasi kemampuan siswa, 3) siswa didorong untuk belajar sendiri, belajar aktif melalui konsep-konsep, prinsip-prinsip, 4) mengajarkan siswa untuk memahami isi dan proses dalam waktu yang bersamaan, 5) siswa belajar menyelesaikan masalah, mengevaluasi solusi, dan berfikir logis, hal ini dapat dilihat pada saat siswa bekerja bersama kelompok mengemukakan hipotesis dan pada saat siswa bertanya kepada guru serta pada saat siswa mengemukakan pendapat atau mengemukakan apa yang telah siswa dapat dalam proses pembelajaran tersebut, 6) siswa juga dituntut belajar sambil berbuat sehingga siswa lebih mengingat apa yang telah siswa pelajari.

Kelemahan yang menyebabkan pencapaian hasil belajar belum maksimal dan peningkatan hasil belajar masih tergolong rendah, kelemahan tersebut antara lain, 1) siswa yang memilih duduk diam dan menunggu hasil yang diperoleh oleh temannya daripada bergabung membantu temannya untuk memperoleh data tersebut, 2) keterbatasan peneliti dalam mengalokasikan waktu pada saat siswa mengajukan hasil diskusi sehingga tidak semua kelompok dapat menyajikan hasil diskusi kelompoknya, 3) siswa masih kurang memiliki kemauan sendiri untuk mempelajari sendiri materi listrik dinamis sehingga dalam penelitian ini penerapan model pembelajaran discovery learning kurang mencapai karakteristik model pembelajaran discovery learning yang seharusnya.

Model pembelajaran discovery learning dapat dilakukan seefektif mungkin jika sampel penelitian merupakan siswa-siswi yang memiliki pemahaman yang cukup untuk materi yang diajarkan, jumlah siswa dalam satu kelas tidak terlalu banyak dan mahasiswa calon guru memiliki kemampuan pengelolaan kelas yang baik maka model pembelajaran berdasarkan masalah dapat dijadikan salah satu model pembelajaran yang dapat meningkatkan hasil belajar siswa untuk materi fisika.

Hasil observasi keseluruhan yang dilakukan terhadap aktivitas siswa pada pertemuan I sampai pertemuan III antara kelas kontrol dan kelas eksperimen menunjukkan hasil yang sangat berbeda, hal ini menunjukkan adanya peningkatan aktivitas siswa menjadi lebih baik di kelas eksperimen karena model pembelajaran discovery learning mengarahkan siswa untuk lebih aktif, kreatif dalam melakukan kegiatan pembelajaran yang disertai praktikum dan berfikir kritis sehingga siswa lebih termotivasi untuk memahami materi yang disampaikan.

Meningkatnya aktivitas belajar siswa di kelas eksperimen ternyata memiliki hubungan yang sangat rendah dalam mempengaruhi peningkatan hasil belajar siswa. Hasil belajar siswa yang diajarkan dengan menggunakan model pembelajaran berdasarkan masalah diperoleh lebih tinggi dibandingkan dengan hasil belajar siswa dengan model konvensional, sama halnya dengan penilaian aktivitas 
belajar siswa. Penilaian aktivitas di kelas eksperimen adalah 65,40.

Kategori soal untuk mengetahui hasil belajar siswa merupakan kategori soal C4, C5, dan C6 sesuai dengan revisi taksonomi bloom. Kelas kontrol lebih unggul untuk kategori soal C4, hal ini disebabkan di kelas kontrol penjelasan tentang soal soal analisis lebih cepat dipahami siswa karena dijelaskan dengan metode ceramah, tetapi sangat rendah untuk kategori soal C5 dan C6. Pada kelas eksperimen lebih unggul untuk kategori soal C5 dan C6, hal ini disebabkan soal-soal C5 dan C6 mengacu kepada kerja nyata pada saat praktikum dilakukan untuk menyelesaikan masalah yang diberikan, siswa pada kelas eksperimen menjadi lebih memahami cara menyelesaikan kategori soal C5 dan C6.

\section{KESIMPULAN}

Kesimpulan bahwa kemampuan hasil belajar dan aktivitas belajar menggunakan discovery learning lebih baik bila dibanding dengan menggunakan metoda konvensional. Penggunaan waktu dalam pembelajaran harus diperhatikan dengan baik.

\section{DAFTAR PUSTAKA}

Goldberg, J.R., Nagurka, M., (2012), Enhancing The Engineering Curriculum: Defining Discovery Learning At Marquette University, Journal of Biomedical Engineering Faculty Research and Publications 10 (1) : pp 405-410.

Honomichl, R.D.,Chen, Z., (2012), The Rrole Of Guidance In Children's Discovery Learning, Journal of Wires Cognitive Science(3) : pp 615-622.

Hosnan, M., (2014), Pendekatan Saintifik Dan Kontekstual Dalam Pembelajaran Abad 21 Kunci Sukses Implementasi Kurikulum 2013, Ghalia Indonesia, Bogor.
Kamel, A., Mahmoud, A., (2014), The Effect Of Using Discovery Learning Strategy In Teaching Grammatical Rules To First Year General Secondary Student On Developing Their Achievement and Metacognitive Skills, Journal of Innovation and Scientific Research 5 (2) : pp 146-153.

Kusuma, T.A., Indrawati, Harijanto, A., (2015), Model Discovery Learning Disertai Teknik Probing Prompting Dalam Pembelajaran Fisika Di MA, Journal of Pendidikan Fisika 3 (4) : pp336-341.

Putrayasa, I.M., Syahruddin, H., Margunayasa, I.G., (2014), Pengaruh Model Pembelajaran

Discovery Learning Dan Minat Belajar Terhadap Hasil Belajar IPA Siswa, Journal ofMimbar PGSD Universitas Pendidikan Ganesha 2 (1) : Hal: 1-11.

Syafi'i, A., Handayani, L., Khanafiyah, S., (2014), Penerapan Question Based Discovery Learning Pada Kegiatan Laboratorium Fisika Untuk Meningkatkan Keterampilan Proses SAINS, Journal of Unnes Physics Education 3(2): Hal :1-8.

Sudjana, N. 2005. Metoda Statistika. Tarsito, Bandung

Tran, T., Nguyen, N.G., Bui, M.D., (2014), Discovery Learning With The Help Of The Geo Gebra Dynamic Geometry Software, Journal of Learning, Teaching and Educational Research 7 (1): pp44-57.

Uside, O.N., Barchok, K.H., Abura, O.G., (2013), Effect Of Discovery Method On Secondary School Student's Achievement In Physics Kenya, Journal of Social Sciences \& Humanities 2 (3) : pp2186-8492

Widiadnyana, I.W., Sadia, I.W., Suastra, I.W., (2014), Pengaruh Model Discovery Learning 
Jurnal Inpafi

Volume 3 Nomor 4 Nopember 2015

Terhadap Pemahaman

Konsep IPA dan Sikap Ilmiah

Siswa SMP, Journal of Program

Pascasarjana Universitas

Pendidikan Ganesha4: Hal : 1-13. 